\title{
Kepala Daerah Dalam Percepatan Pembangunan Pendidikan Di Provinsi Jambi
}

\author{
Sakban, Musa, Neni \\ Dosen Universitas Muhammadiyah Riau \\ Dosen STIT Al-Falah Rimbo Bujang Kabupaten Tebo Jambi \\ 3Dosen Sekolah Tinggi Agama Islam Rokan \\ Corresponding email: sakban80@umri.ac.id
}

\begin{abstract}
This study aims to examine the accountability of regional heads in accelerating educational development in Jambi Province. The question in this study is why the accountability of regional heads has not been able to accelerate education development in Jambi Province. This study uses a qualitative research approach that is descriptive analytical. The data was collected by means of observation, interview and documentation techniques. Determination of research subjects using purposive sampling technique. Data analysis techniques with data reduction, data presentation and drawing conclusions and verification. Reliability with extension techniques, participation, accuracy of observations and triangulation of data. The results of this study indicate that the efforts of regional heads to accelerate education development in Jambi Province are carried out in the form of a five-year education program or master plan, then strengthening education human resources through a number of training, upgrading, activation of professional work groups and provision of facilities and infrastructure according to existing programs.
\end{abstract}

\begin{abstract}
Abstrak
Penelitian ini bertujuan untuk mengkaji akuntabilitas kepaladaerah dalam percepatan pembangunan pendidikan di Provinsi Jambi. Pertanyaan dalam penelitian ini adalah mengapa akuntabilitas kepala daerah belum mampu membuat percepatan pembangunan pendidikan di Pprovinsi Jambi. Penelitian ini menggunakan pendekatan penelitian kualitatif bersifat deskriptif analitis. Pengumpulan data dilakukan dengan teknik observasi, wawancara dan dokumentasi. Penetuan subjek penelitian menggunakan teknik purposive sampling. Teknik analisis data dengan reduksi data, penyajian data dan penarikan kesimpulan serta verifikasi. Keterpercayaan dengan teknik perpanjangan, keikutsertaan, ketelitian pengamatan dan triangulasi data. Hasil penelitian ini menunjukkan bahwa upaya kepala daerah dalam percepatan pembangunan pendidikan di Provinsi Jambi dilakukan dalam bentuk penyusunan program pendidikan atau masterplan selama lima tahun, lalu memperkuat SDM pendidikan melalui sejumlah pelatihan, penataran, aktivasi kelompok kerja profesi dan penyediaan sarana dan prasarana sesuai program yang ada.
\end{abstract}




\section{Pendahuluan}

Salah satu visi dan misi pengembangunan Provinsi Jambi adalah meningkatkan kualitas atau mutu pendidikan. Mutu itu relatif. Ukurannya terpunuhinya kebutuhan, keinginan dan harapan pengguna. ${ }^{1}$ Untuk itu, dapat dikatakan bahwa orang dapat saja mengartikan mutu berdasarkan kriterianya sendiri seperti berikut ini; melebihi diri yang dibayangkan dan diinginkan, kesesuaian antara keinginan dengan kenyataan pelayanan, sangat cocok dalam pemakaian, selalu dalam perbaikan dan penyempurnaan terus-menerus, dari awal tidak ada kesalahan, membanggakan dan membahagiakan pelanggan, dan tidak ada cacat atau rusak. ${ }^{2}$

Pendidikan bermutu atau mutu pendidikan adalah pendidikan yang mampu melakukan proses pematangan kualitas peserta didik yang dikembangkan dengan cara membebaskan peserta didik dari ketidaktahuan, ketidakmampuan, ketidakberdayaan, ketidakbenaran dan dari buruknya akhlak dan keimanan. ${ }^{3}$ Peningkatan mutu tidak terlepas dari konsep mutu pendidikan, karena peningkatan mutu pendidikan ditentukan oleh peningkatan aspek/indikator dari mutu pendidikan itu sendiri. Hingga saat ini belum ada kespakatan yang jelas tentang pengertian mutu pendidikan. Literatur yang membahas mutu pendidikan masih tergolong terbatas. Sallis mengemukakan konsep mutu dapat dipandang dari segi absolut dan relatif, langka dan mahal adalah dua nilai penting dalam konsep mutu. Sedangkan dari segi pandang relatif, mutu memiliki dua aspek yaitu ksesuaian dengan spesifikasi dan pemenuhan kebutuhan pelanggan. ${ }^{4}$ Pernyataan ini menunjukkan bahwa konsep mutu tidak mudah dibangun, karena dari kedua pengertian mutu ini memberikan makna bahwa mutu tergantung kepada orang yang memberikan penilaian. Dalam hal ini, mutu menurut seseorang tidak sama dengan menurut orang lain.

Peningkatan mutu pendidikan salah satu kebijakan pemerintah daerah dalam sektor pendidikan. Selama ini pemerintah daerah telah banyak melakukan berbagai usaha dalam rangka peningkatan pendidikan. Antara lain mengadakan penataran para guru, menyediakan buku-buku pendidikan, pengembangan kurikulum yang ada dan menerbitkan peraturan perundangundangan. Selain itu juga pemerintah telah menambah gedung-gedung sekolah, laboratorium, komputer, laboratorium bahasa dan lain-lain.

Lembaga pendidikan dengan pendekatan bisnis juga harus memiliki sistem dan infrastruktur yang dijiwai oleh budaya perusahaan yang unggul great corporate culture). Logika bisnis yang bertumpu pada pola pikir materialistik, ekonomis, dan pragmatis ini telah menggeser praktik pendidikan yang didasarkan pada logika

${ }^{1}$ Sudarwan Danim, Otonomi Manajemen Pendidikan, (Bandung: Alfabeta, 2010), hal.146.

${ }^{2}$ Engkoswara dan Aan Komariah, Administrasi Pendidikan, (Bandung: Alfabeta, 2010), hal.

304.

${ }^{3}$ Mulyasana, Pendidikan Bermutu dan Berdaya Saing, (Bandung: Remaja Rosdakarya, 2012), hal.

${ }^{4}$ Edward Sallis, Total Qualiti Management in Education, Terj. Ahmad Ali Riyadi (Yokyakarta: Ircisod, 2006), hal. 51-55. 
filsafat, agama, politik dan ilmu pengetahuan sebagaimana tersebut di atas. ${ }^{5}$ Hal ini selaras dengan prioritas prioritas gubernur dan wakil gubernur terpilih adalah:

1. Menigkatkan kelas, status jalan, bandar udara, pembangunan jalan baru dan pelabuhan

2. Percepatan pembangunan. infrastruktur listrik

3. Meningkatkan kualitas dan ketersediaan jaringan irigasi dan air bersih

4. Percepatan pembangunan infrastruktur pendidikan, kesehatan dan perumahan

5. Pemerataan akses terhadap pendidikan berkualitas

6. Peningkatan peran agama dan budaya dalam pembangunan

7. Peningkatan peran pemuda dan prestasi olahraga

8. Peningkatan perlindungan dan kesejahteraan social

9. Meningkatkan perekonomian daerah

10. Peningkatan pembangunan pertanian dan ketahanan pangan

11. Peningkatan kualitas dan kelestarian sumber daya air, lahan dan tambang.

12. Peningkatankualitas pengelolaan mitigasiperubahan iklim dan kelestarian

13. Peningkatan Tata pemerintahan yang baik

14. Peningkatan jaminan kepastian dan perlindungan hokum

15. Peningkatan kesetaraan gender. ${ }^{6}$

Salah satu point prioritas gubernur adalah percepatan pembangunan infrastruktur pendidikan dan pemerataan akses terhadap pendidikan berkualitas. Dua aspek pembangunan pendidikan ini sudah mulai dikerjakan dengan gubernur terpilih. Pemerintah Provinsi Jambi, juga terus berupaya untuk memenuhi sarana dan prasarana pendidikan dan kesehatan, dalam kerangka peningkatan kualitas SDM di Provinsi Jambi. Dalam kaitan ini, peningkatan kualitas sumber daya manusia, harus mendapat perhatian melalui peningkatan kualitas pelayanan, pemerataan akses, serta kuantitas pelayanan sosial dasar, terutama peningkatan layanan pendidikan yang berkualitas dan peningkatan pelayanan kesehatan. ${ }^{7}$

Pada dekade terakhir ini dunia pendidikan nasional sedang mengalami berbagai perubahan yang cukup mendasar, berkaitan dengan Undang-undang Sistem Pendidikan Nasional, manajemen dan kurikulum, yang diikuti oleh perubahan-perubahan teknis lainnya. Perubahan- perubahan tersebut diharapkan pada gilirannya dapat memecahkan berbagai permasalahan pendidikan, baik masalah konvensional maupun kontemporer. Disamping itu, perubahan-perubahan tersebut diharapkan pula agar mampu menciptakan iklim yang kondusif bagi peningkatan kualitas pendidikan, dan pengembangan sumber daya manusia untuk mempersiapkan bangsa Indonesia memasuki era kesejagatan dalam persaingan global, terutama dalam bidang pendidikan.

${ }^{5}$ Abuddin Nata, Kapita Selekta Pendidikan Islam, (Jakarta: RajaGrafindo Persada, 2012), hal.

28.

${ }^{6}$ Laporan Keterangan Pertanggungjawaban Gubernur Jambi Tahun Anggaran 2012

7 MetroJambi, Pembangunan Infastruktur, Dorong Percepatan Pertumbuban Ekonomi Daerah dan Sektor Rill, (Metrojambi.Com Edisi, Senin, 06 Januari 2014 01:07) 
Perubahan mendasar tersebut antara lain berkaitan dengan masalah manajemen, yang semula sentralisasi sekarang diarahkan menjadi desentralisasi. Upaya yang dilakukan pemerintah ini tiada lain bertujuan untuk mendobrak mutu pendidikan Indonesia yang sejak dulu selalu dilanda banyak masalah, sehingga mutu pendidikan kita masih tergolong rendah dan sulit untuk bersaing dengan Negaranegara lain dalam kancah global.

Menciptakan sumber daya manusia yang berkualitas, maka perlu optimalisasi pendidikan, untuk itu pemerintah Provinsi Jambi sangat memperhatikan percepatan pembangunan dalam dunia pendidikan yang tertuang dalam poin 4 pada prioritas gubernur dan wakil gubernur terpilih. Percepatan pembangunan pendidikan di Provinsi Jambi diperlukan akuntabilitas kepala daerah di tingkat kabupaten/Kota yang melakukan sejumlah kebijakan-kebijakan yang tepat sasaran sesuai keadaan masyarakat Jambi.

Pemerintah Indonesia melalui pemerintah daerah juga sudah memberikan keleluasaan untuk mengatur, membenahi, meningkatkan dan mengembangkan pendidikan sesuai dengan kebutuhan daerahnya masing-masing, di antaranya Kota Jambi, Kabupaten Tebo dan Kabupaten Sarolangun. Berdasarkan grand tour di Provinsi Jambi, ditemukan bahwa Provinsi Jambi memiliki potensi dalam hal percepatan pembangunan pendidikan, bila seorang kepala daerah mampu bersikap terbuka dan setiap program yang telah dicanangkan dapat dipertanggung jawabkan dengan baik kepada publik atau adanya transparasi publik. Hanya saja permasalahan yang ditemuan bahwa:

Pertama, kepala daerah kurang tanggap atas kebutuhan/hak pengguna jasa layanan pendidikan, indikasinya kondisi pendidikan di Provinsi Jambi ternyata masalah pendidikan tetap belum menjangkau seluruh masyarakat dan belum ada sekolah untuk masyarakat setempat. Sekolah Dasar saja tidak ada, jadi pendidikan belum merata, masyarakat di beberapa wilayah Provinsi Jambi sangat mendambakan berdirinya sekolah untuk anak-anak mereka. Akibatnya untuk bersekolah, masyarakat harus ke daerah lain dengan jarak tempuh yang jauh.

Kondisi pendidikan di Provinsi Jambi masih menghadapi kurangnya ketersediaan sarana dan prasarana pendidikan dasar dan menengah. Dari jumlah keseluruhan dari penduduk usia sekolah (terutama untuk jenjang pendidikan SLTP dan SLTA) jumlah sarana dan prasarana yang ada secara nyata belum mencukupi, di mana kondisi ideal rasio murid dan guru di jenjang Sekolah Menengah Pertama adalah 1: 15 dan jenjang Sekolah Menengah Atas adalah 1: 29, sementara itu kondisi eksisting ratio murid dan guru di jenjang SLTP dan SLTA hanya sebesar 1: 11. Hal ini menjadi tantangan kedepan bagi Provinsi Jambi dihadapkan dengan perkiraan jumlah usia sekolah yang akan melanjutkan pendidikan.

Kedua, belum mampu pengguna jasa untuk meminta pertanggung jawaban kepada pembuat kebijakan atau manajer atas janji atau keputusan mereka. Sudah banyak elemen masyarakat menyampaikan kondisi riil pendidikan di daerahnya masing-masing, namun pemerintah Provinsi Jambi belum melakukan banyak perubahan atas kondisi itu. Banyaknya anak-anak usia sekolah yang tidak 
melanjutkan pendidikan disebabkan jauhnya lokasi sekolah juga menjadi tantangan tersendiri bagi kebijakan pemerintah dan pemerintah belum banyak melakukan percepatan pembangunan pendidikan untuk mengatasi permasalahan yang ada.

\section{Metodologi Penelitian}

Pada aspek metodologi penelitian menggunakan pendekatan kualitatif. Pendekatan yang digunakan dalam penelitian ini mengenai akuntabilitas kepala daerah dalam percepatan pembangunan pendidikan di Provinsi Jambi. Metode penelitian kualitatif adalah metode penlitian yang berlandaskan pada filsafat postpusivisme, digunakan untuk meneliti pada kondisi obyek yang alamiah, (sebagai lawannya adalah eksperimen) di mana peneliti adalah sebagai instrumen kunci, pengambilan sampel sumber data dilakukan secara purposive dan snowball, teknik pengumpulan dengan trainggulasi (gabungan), analisi data bersifat indukatif/kualitatif, dan hasil penelitian lebih menekankan makna dari pada generalisasi ${ }^{8}$. Untuk melihat akuntabilitas kepala daerah dan percepatan pembangunan pendidikan, dalam penelitian ini, peneliti berupaya mencermati, memahami dan mendeskripsikan apa yang diperoleh dilapangan penelitian sesuai dengan kenyataan. Dalam penelitian kualitatif, kehadiran peneliti sedapat mungkin diupayakan tidak mengubah suasana yang ada, dengan berbagai teknik pengumpulan data yang dilakukan oleh peneliti secara wajar sebagaimana adanya.

Jenis penelitian ini adalah penelitian lapangan (field research) penelitian yang dilakukan secara intensif, rinci dan mendalam serta objeknya mengenai gejalagejala atau peristiwa-peristiwa yang terjadi pada suatu organisasi atau lembaga.Sehingga penelitian ini juga bisa disebut kasus (case studies) dengan pendekatan deskriptif-kualitatif. ${ }^{9}$ Studi kasus atau penelitian kasus adalah penelitian tentang status subjek penelitian yang berkenaan dengan suatu fase spesifik atau khas dari keseluruhan personalitas.Subjek penelitian dapat saja individu, kelompok, lembaga maupun masyarakat.Peneliti ingin mempelajari secara intensif latar belakang serta interaksi lingkungan dari unit-unit social yang menjadi subyek. Tujuan studi kasus adalah untuk memberikan gambaran secara mendetail tentang latar belakang, sifat-sifat serta karakter-karakter yang khas dari kasus, ataupun status dari individu, yang kemudian dari sifat- sifat khas di atas akan dijadikan suatu hal yang bersifat umum.

Jenis penelitian ini digunakan untuk meneliti akuntabilitas kepala daerah dalam percepatan pembangunan pendidikan di Provinsi Jambi. Penelitian ini ditinjau dari segi metodologik, penelitian ini merupakan jenis penelitian kualitatif. Adapun yang dimaksud dengan penelitian kualitatif menurut Bogdan dan Taylor sebagai prosedur penelitian yang menghasilkan data deskriptif berupa kata-kata

${ }^{8}$ Sugiyono, Metode Penelitian Pendidikan: Pendekatan Kuantitatif, Kualitatif dan R \&D, (Bandung: Alfabeta, 2013), 14

${ }_{9}$ Suharsimi Arikunto, Prosedur Penelitian: Suatu Pendekatan Praktik, Jakarta: Bumi Aksara, 2013), 100 . 
tertulis atau lisan dari orang-orang dan perilaku yang diamati. Menurut mereka pendekatan ini diarahkan pada latar atau individu tersebut secara menyeluruh (holistik).Jadi dalam hal ini tidak boleh mengisolasikan individu atau organisasi ke dalam variabel atau hipotesis, tetapi perlu memandangnya sebagai bagian dari sesuatu keutuhan. ${ }^{10}$ Metodologi penelitiannya dilakukan pada kondisi yang alamiah (natural setting). ${ }^{11}$ Data yang dikumpulkan adalah berupa kata-kata, gambar, dan bukan angka- angka.Hal itu disebabkan oleh adanya penerapan metode kualitatif. Selain itu, semua yang dikumpulkan berkemungkinan menjadi kunci terhadap apa yang diteliti.

\section{Hasil dan Pembahasan}

Ada beberapa uya yang dilakukan kepala Daerah dalam percepatan pembangunan yait; Pertama, Upaya yang tidak kalah pentingnya adalah memberikan masukan dan pengertian dalam setiap pertemuan akan pentingnya pertemuan dan kerja sama serta kebersamaan yang mesti diwujudkan antara sekolah, orang tua dan masyarakat. Oleh karena itu dalam pertemuan-pertemuan, semua wali murid diberikan kesempatan dan kebebasan untuk mengkritik, memberikan saran untuk kemudian dicarikan solusinya dalam pertemuan tersebut. Upaya membuat kesan dan kesadaran bahwa para wali murid memiliki tugas yang sama dengan guru, rasa memiliki kebersamaan terhadap sekolah guna mewujudkan tujuan pendidikan anakanaknya. Kepemimpinan kepala dinas pendidikan juga mengatakan bahwa guruguru yang bertanggung jawab akan tugas merupakan pendukung utama. Kepala dinas pendidikan juga menambah adanya perhatian yang besar dari komite dan pemerintah. Meskipun perhatian dan partisipasi orang tua untuk sekolah kurang sekali.

Pengambilan keputusan dapat dipandang suatu tolak ukur utama dari kinerja sebagai seorang kepala dinas pendidikan. Semua hasil keputusan pemimpin akan menjadi acuan berpikir, bersikap dan berbuat bagi seluruh komunitas sekolah. Oleh karena itu, kepala dinas pendidikan sebagai figur sentral sekolah perlu menggali prinsip, konsep dan teknik pembuatan keputusan pendidikan yang terus berkembang. Termasuk di sini sebagai administrator adalah kepala dinas pendidikan. Kepala dinas pendidikan sebagai administrator termotivasi dan kemampuan untuk merencanakan serta melaksanakan semua administrasi sekolah yang tertib, aman, cepat dan terkendali. Sebagai mana di awal pembahasan ini bahwa Dinas Pendidikan Kabupaten Muaro Jambi mengembangkan kegiatan lainnya. Salah satunya adalah pendidikan keterampilan. Banyak masyarakat yang menyekolahkan anaknya tidak hanya berasal dari lingkungan terdekat sekolah saja akan tetapi juga dari luar kecamatan Jambi Selatan. Menurut kepala dinas pendidikan bahwa masyarakat yang mengirimkan anaknya ke SD/SMP negeri hal. 3 .

${ }^{10}$ Lexy J. Moleong, Metodologi Penelitian Kualitatif, (Bandung: Remaja Rosdakarya, 2017), ${ }^{11}$ Sugiono, op. cit, hal. 14. 
Kabupaten Muaro Jambi berasal dari berbagai etnis, ideologis. Secara strata sosial masyarakat mereka berada pada posisi keluarga tidak mampu sampai pada level tingkat atas. Pernyataan kepala dinas pendidikan diatas menunjukkan memang sudah umum rata-rata elemen masyarakat mengirim anaknya sekolah di SDN/SMP negeri Kabupaten Muaro Jambi berasal dari semua lapisan yaitu dari keluarga tidak mampu sampai pada level tingkat atas.

Kedua, Peningkatan Kinerja Pendidik dan Tenaga Kependidikan. Keberhasilan seorang kepala dinas pendidikan dalam memimpin sekolah pada tiaptiap jenjang pendidikan apapun, baik lembaga pendidikan formal, informal maupun non-formal, sehingga tercapai tujuan yang ingin diraih desebabkan salah satunya oleh kemampuan kepala dinas pendidikan dalam mengelola tenaga kependidikan yang tersedia di sekolah. Dalam hal ini peningkatan perilaku tenaga kependidikan di sekolah.

Sumber Daya Manusia (SDM) di Dinas Pendidikan Kabupaten Muaro Jambi secara kualitas memang relatif memadai. Di antara jumlah kelas dan jumlah guru yang dibutuhkan telah memadai. Hal ini dilihat dari mata pelajaran yang harus diajarkan kurikulum yang ada ternyata sesuai dengan latar belakang pendidikan guru yang ada. Untuk kasus ini diperkuat dengan apa yang dikatakan kabid SD di Dinas Pendidikan bahwa percepatan pembangunan pendidikan diarahkan pada pemenuhan kualifikasi pendidikan guru. Berdasarkan informasi tersebut maka diperoleh keterangan bahwa upaya utama secara internal yang berkembang pada Dinas Pendidikan Kabupaten Muaro Jambi yaitu SDM yang harus memenuhi kualifikasipendidikan.

Permasalahan lain yang terus ditingkatkan adalah disiplin kerja guru di sekolah. Disiplin sekolah apabila dikembangkan dan diterapkan dengan baik, konsisten dan konsekuen akan berdampak positif bagi kehidupan dan prilaku peserta didik. Disiplin dapat mendorong mereka belajar dengan kongkrit dan praktik hidup di sekolah tentang hal-hal positif: melakuan hal-hal yang lurus dan benar, menjauhi hal-hal yang negatif. Dengan pemberlakukan disiplin, peserta didik belajar beradaptasi dengan lingkungan yang baik itu, sehingga muncul keseimbangan diri dalam hubungan dengan orang yang lain. Jadi, disiplin menata perilaku seseorang dalam hubunganya di tengah-tengah lingkungannya. Dalam mendidik disiplin berperan mempengaruhi, mendorong, mengendalikan, mengubah, membina dan membentuk prilaku-prilaku tertentu sesuai dengan nilainilai yang ditanamkan, diajarkan dan diteladankan. Menurut salah satu guru SD di maruo jambi mengatakan bahwa tidak lagi ada guru yang tidak disiplin karena guru tersebut masih banyak yang dikerjakan selain aktivitas di sekolah. Kondisi ini menjadikan kegiatan pembelajaran lancar seperti guru yang disiplin datang dan pulang sesuai jadwal yang ada atau yang ditentukan sekolah. Demikian juga kepala dinas pendidikan juga melakukan hal sama terkait disiplintersebut.

Sebagian tujuan pendidikan ditujukan pada perasaan kelompok. Anggota kelompok harus saling menyukai, saling menghormati, saling mempercayai. Mereka yakin bahwa setiap orang dalam kelompok dapat bertanggung jawab sepenuhnya. 
Jika tidak, ia akan melakukan usaha bersama. Sebagian proses memimpin yang harus dilakukan oleh kepala dinas pendidikan adalah menolong guru mengembangkan sikap dan kariernya. Hal itu merupakan langkah pertama manuju grup self discipline, seorang pemimpin harus rajin mengadakan pertemuan dengan staf untuk merumuskan tujuan yang diharapkan sesuai dengan kemampuan anggota. Anggota kelompok harus melihat yang tercakup dalam tujuan, dipandang dari sudut waktu dan tenaga sebelum tersedia menerima tanggung jawab. Tanpa menerima tanggung jawab secara suka rela tidak ada yang mendasari grup self discipline. Agar disiplin kelompok terbina dengan baik pemimpin dalam hal ini kepala dinas pendidikan harus sudah terlatih sehingga patuh terhadap tujuan kelompok. Jika disiplin kelompok terwujud kepala dinas pendidikan dapat meningkatkan partisipasi warga sekolah semaksimal mungkin. Potensi setiap anggota dapat dimanfaatkan seefektifmungkin.

Menurut kepala sekolah pekerjaan yang harus diselesaikan harus dibagi-bagi kepada staf, kepala sekolah mengatakan bahwa dalam menjalankan tugas-tugas di sekolah ini saya selalu melibatkan guru-guru yang ada, sebab saya sadar keterbatasan saya sebagai manusia. Oleh karena itu saya selalu melibatkan staf-staf saya. Saya yakin mereka mampu menerima tugas-tugas yang saya berikan sebab mereka bekerja sesuai dengan keahlian yang dimiliki.

Untuk mencapai tujuan pendidikan, Dinas Pendidikan Kabupaten Muaro Jambi banyak faktor yang harus diperhatikan, salah satunya kualitas tenaga pengajar yang ada. Dari sisi kualitas tenaga pengajar di Dinas Pendidikan Kabupaten Muaro Jambi menurut kepala dinas pendidikan sudah cukup baik, ini diindikasikan dengan kualifikasi mengajar bidang studi sesuai dengan kualifikasi ijazah yang mereka miliki. Begitu juga mayoritas pendidikan terakhir semua guru adalah sarjana. Namun bukan berarti kepala dinas pendidikan tidak memotivasi para tenaga pengajar yang ada. Dari sisi kualitas tenaga pengajar di Dinas Pendidikan Kabupaten Muaro Jambi. Kepala dinas pendidikan dalam rangka mempercepat pencapaian visi, misi tujuan dan sasaran yang akan diarahkan sekolah, diperlukan langkah-langkah strategis yang diperlukan dalam menyelesaikan permasalahanpermasalahan yang muncul setiap saat dengan beragam permasalahan sekolah yang serba kompleks itu, jikalau semua problem tidak diatasi secepatnya maka akan berdampak dan mampu menyikapi yang sedang dan akan dialami oleh peserta didik, guru, staf tata usaha dan tenaga kependidikan lainnya yang berpengaruh terhadap cita-cita yang mau dicapai. Hal ini dibenarkan oleh pengawas SMP menjelaskan bahwa kepala dinas pendidikan tidak bekerja sendirian. Kepala dinas pendidikan mendelegasikan tugas-tugasnya yang tidak sempat dikerjakan sendirian, kepala dinas pendidikan tidak pernah mengintervensi tugas-tugas yang diberikan pada kami, kepala dinas pendidikan memberi kepercayaan penuh padastafnya.

Kepala dinas pendidikan menganalisis kemampuan bawahannya sebelum tugas yang akan diberikan. Sebagai contoh dalam hal ini pengutusan guru untuk mengikuti seminar. Sebelum mengutus guru yang akan mengikuti seminar lokakarya tersebut kepala dinas pendidikan mengkoordinasikan terlebih dahulu yang Jurnal WARAQAT Volume V, No. 2, Juli - Desember 2020 | 118 
bersangkutan tentang kelayakannya. Hal ini kepala dinas pendidikan sangat berhatihati sebelum mengambil keputusan, kepala dinas pendidikan tidak ingin terjadi gesekan antar sesama guru disebabkan penilaian sepihak kepala dinas pendidikan. Kepala dinas pendidikan benar-benar berharap bahwa yang menjadi duta dari Dinas Pendidikan Kabupaten Muaro Jambi ini adalah benar-benar mempunyai kemampuan, baik secara intelektual maupun moral. Menurut salah satu kepala SDN di Muaro Jambi bahwa kepala dinas pendidikan juga memperhatikan karir guru dan kesejahteraan tenaga kependidikan. Perhatian kepala dinas pendidikan yang berusaha meningkatkan karir guru, tidak hanya sekedar kata-kata belaka. Sebagai contoh bagi guru yang ingin melanjutkan pendidikan ke jenjang yang lebih tinggi dengan sponsor pemerintah atau swasta kepala dinas pendidikan memberi rekomendasi.

Kepala dinas pendidikan terus menerus berusaha memompa semangat para tenaga kependidikan dalam keadaan apapun untuk tetap menjaga eksistensi bawahannya. Hal ini dilakukan kepala dinas pendidikan dikarenakan kepala dinas pendidikan menyadari bahwa untuk memotivasi dengan insentif untuk saat ini belum dapat dipenuhi, disebabkan minimnya keuangan yang dimiliki lembaga. Walaupun kesejahteraan belum terpenuhi, tetapi kepala dinas pendidikan semaksimal mungkin menyediakan peralatan ataupun perlengkapan yang dibutuhkan guru ataupun karyawan guna menunjang kinerja mereka dalam melangsungkan proses pendidikan Dinas Pendidikan Kabupaten MuaroJambi.

Kepala dinas pendidikan sebagai pemimpin tepat melakukan controlling terhadap kinerja bawahannya. Pemantauan dilakukan kepala dinas pendidikan terhadap kinerja guru dan karyawan yang kurang bersungguh-sungguh dalam bekerja, kepala dinas pendidikan tidak segan- segan member kritik, teguran sanksi. Sebagaimana dikatakan kepala dinas pendidikan bahwa dalam menyikapi fenomena guru dan karyawan yang bermalas-malsan atau bekerja kurang sungguh-sungguh, seperti itensitas keterlambatan datang pada jam sekolah serta pulang sebelum jam kantor selesai atau bagi guru yang tidak masuk kelas untuk mengajar maka akan saya tegur baik secara lisan maupuntertulis.

Menurut pengamatan peneliti kepala dinas pendidikan selalu bersikap tegas dalam memberikan teguran kepada guru. Ini terlihat ketika ada salah seorang guru yang datang terlambat dalam mengajar, sehingga ketika ia datang ke kelas tinggal beberapa murid saja, kejadian seperti ini tidak hanya terjadi satu kali saja melainkan sering terjadi, kebet sewaktu peneliti datang kesekolah untuk observasi dan wawancara keadaan seperti ini sedang berlansung. Sebagai agen perubahan melalui kegiatan pembenahan kepemimpinan sekolah dengan wadah pembinaan sosial yang tepat. Kenyataan menunjukkan bahwa tingkat kemajuan sekolah sangat ditentukan oleh sejauhmana tingkat kemajuan kepemimpinan kepala dinas pendidikan di dalam mengembangkan kemampuan guru dalam mengelola kelas.

Sesuai dengan wawancara penulis dengan guru di SMPN Muaro Jambi salah satu guru mengemukakan pendapatnya bahwa pengalaman mengajar atau masa kerja sangat mendukung terlaksananya proses pembelajaran, namun yang menjadi 
kendala mereka selama ini adalah kurangnya pengalaman akan pelatihan-pelatihan guru mata pelajaran jarang sekali mereka ikut bahkan sama sekali ada yang belum pernah mengikuti penataran-penataran atau pelatihan guru mata pelajaran. Karena pengalaman itu pula, maka sehingga tidak banyak kreativitas untuk memberdayakan kelas yangada.

Kepala dinas pendidikan tidak mentargetkan bagaimana guru mengembangkan profesionalitas, dalam arti kepala dinas pendidikan tersebut memiliki perencanaan seirama dengan perencanaan pelaksanaan workshop, penataran, dan diklat, karena kapan guru-guru dipanggil untuk mengikuti kegiatan tersebut kepala dinas pendidikan akan mengirimkan sesuai dengan jurusan yang diminta. Hasil pengamatan di lapangan menunjukkan bahwa pengiriman guru-guru untuk mengikuti penataran yang diselenggarakan secara nasional telah dilakukan dua kali pada guru. Tercatat sejumlah pengiriman guru mengikuti penataran dengan berbagai materi yang dibicarakan. Materi yang paling dominan diikuti oleh guru adalah pelatihan guru bidang studi.

Wawancara dengan guru di Kabupaten Muaro Jambi yang mengatakan bahwa sekolah ini juga sulit mengarahkan guru-guru untuk mengembangkan kompetensinya dengan mengikuti sejumlah pelatihan dan penataran, kemampuan mereka beranggapan bahwa pendidikan atau diklat diikutinya itu tidak seberapa manfaat bila dihubungan dengan usia atau masa kerja yang sudah mendekati pensiun. Sebagai kepala dinas pendidikan tetap merencanakan pengembangan kompetensi profesional guru itu penting untuk menambah wawasan dan ilmu pengetahuan guru agar dapat melaksanakan tugas dengan baik.

Mengajar memerlukan kinerja yang optimal. Tiap mata pelajaran dan pokok bahasan dalam kegiatan proses pembelajaran membutuhkan metode dan teknik yang bervariasi, pemilihan metode dan teknik tidak dapat begitu saja ditentukan oleh selera dan kemauan seorang guru. Pemilihan tersebut juga tergantung pada pokok bahasan, tujuan belajar yang harus dicapai, bakat, minat dan usia kemampuan peserta didik dan sumber belajar juga ikut mempengaruhi.

Ketiga, Memperbaiki Sistem Informasi Kerja. SDM Dinas Pendidikan Kabupaten Muaro Jambi yang terkait dengan kepemimpinan sekolah itu sendiri. kepala dinas pendidikan adalah sasaran dari pengelolaan kepemimpinan sekolah, maka tanpa itu pengelolan yang dilakukan pihak dinas pendidikan tidak akan terlaksanakan. Wawancara dengan salah satu guru SDN di Muaro jambi mengatakan bahwa realisasi manajemen kepemimpinan dinas pendidikan dan sekolah masih kurang karena tidak didukung dengan sistem informasi kerja yang memadai yang turut serta dalam menentukan kerja kepala dinas pendidikan yang dipilih selama ini. Meskipun kepala dinas pendidikan terus berusaha membenahi kondisi tersebut saatini.

Ketergantungan terhadap program kepemimpinan yang ada mempengaruhi efektivitas pendidikan di Kabupaten Muaro Jambi. Indikasinya tampak dari belum adanya kebijakan peningkatan kepemimpinan sekolah terprogram, dan khas milik sekolah serta belum adanya analisa terhadap visi peningkatan kepemimpinan 
sekolah ke depan. Keadaan ini dapat dipahami bahwa penyelenggaraan sebuah program peningkatan memerlukan sumber dana dan sumber daya yang memadai. Namun demikian depedensi seperti ini akan berimplikasi negatif terhadap matinya kreativitas manajemen sekolah untuk menyetting sendiri program berbasis kebutuhan peningkatan kompetensi kepala dinas pendidikan secara tepat, merata, berkesinambungan.

Kepala dinas pendidikan yang terpilih kurang memiliki dukungan fasilitas yang memadai dalam bekerja. Kepala dinas pendidikan bertanggung jawab dalam mengusahakan fasilitas pendidikan yang dibutuhkan Sekolah dengan berkoordinasi dengan kepala dinas pendidikan. Satu bentuk dari instrumen pendidikan yaitu sarana dan prasarana. Sarana dan prasarana merupakan salah satu faktor yang vital dalam penyelenggaraan pendidikan dan pembelajaran, karena itu apabila sarana dan prasarana kurang mendukung maka penyelenggaraan atau pelaksanaan proses pembelajaran di sekolah tidak dapat berjalan dengan baik. Begitupun sebaliknya, sarana dan prasarana yang mendukung dan lengkap akan memudahkan proses pembelajaran, karena dengan lengkapnya sarana dan prasarana akan memberi variasi pada proses pembelajaran, secara khusus ataupun pelaksanaan sistem pendidikan secara umum di sekolah tersebut tentunya.

Untuk mewujudkan sekolah yang berprestasi, sebenarnya menuntut kelengkapan alat/fasilitas sekolah yang ada. Peningkatan mutu pendidikan harus memperhatikan beberapa faktor yaitu kurikulum, buku-buku pelajaran, dan alat-alat pendidikan lainnya. Dalam rangka meningkatkan mutu pendidikan pada suatu lembaga pendidikan. Faktor di atas menjadi kebutuhan pokok yang harus dimiliki secara lengkap. Bila faktor tersebut tidak lengkap, maka usaha untuk meningkatkan mutu pendidikan tidak terlaksana dengan baik. Hal ini dijelaskan oleh salah satu guru SMPN di Muaro Jambi yang mengatakan bahwa kepemimpinan sekolah dan para guru dalam mengajar di Sekolah ini adalah menyangkut dengan tersedianya sistem informasi kerja berbasis teknologi informasi.

Kepala dinas pendidikan dalam hal ini sebagai manajer pendidikan sangat berperan di dalam perencanaan kinerjanya di sekolah sebagaimana diungkapkan oleh kepala dinas pendidikan, bahwa peningkatan kinerjamerupakan faktor yang sangat penting sebagai pendukung dalam penyampaian informasi kepada warga sekolah di dalam proses pembelajaran, oleh karena itu selaku pengelola sekolah selalu berusaha untuk merencanakan semaksimal mungkin untuk memenuhinya. Perkembangan ilmu pengetahuan dan teknologi telah membawa perubahan yang sangat signifikan terhadap berbagai dimensi kehidupan manusia, baik dalam ekonomi, sosial, budaya maupun pendidikan. Oleh karena itu, agar pendidikan tidak tertinggal dari perkembangan IPTEK tersebut perlu adanya penyesuaianpenyesuaian, terutama sekali yang berkaitan dengan buku-buku sumber belajar yang ada di perpustakaan sekolah. Wawancara dengan salah satu penagwas SDN juga mengatakan bahwa untuk menyediakan informasi yang memadai, maka sistem informasi kerja tetap dibuat dan disediakan pihak dinas pendidikan berdasarkan kebutuhan untuk efektvitas kepemimpinan yangada. 
Fasilitas sistem informasi yang memadai merupakan faktor penunjang terlaksanaannya proses belajar mengajar dengan baik, juga dibantu dengan adanya prasarana yang cukup. Hal ini dapat digunakan guru dan para peserta didiknya untuk lebih giat dalam segala kegiatan belajar di sekolah. Fasilitas dapat berupa gedung dan alat-alat lainnya seperti perpustakaan dan isinya serta prasarana ekstra kurikuler seperti lapangan olah raga dan lain-lain. Sarana dan prasarana ini dapat diperoleh dari usaha bersama dan juga dari bantuan pemerintah setempat serta swadaya masyarakat setempat.

Keempat, Meningkatkan Motivasi dan Pengawasan Kerja Bawahan. Upaya meningkatkan pelaksanaan kepemimpinan dengan melakukan pengawasan pada tahapan ini. Pengawasan merupakan suatu proses manajemen yang memonitor seluruh atau setiap kegiatan untuk memastikan bahwa aktivitas-aktivas diselesaikan dan direncanakan serta memperbaiki setiap penyimpangan yang signifikan. Hal ini sebagaimana diungkapkan oleh kepala dinas pendidikan mengatakan berikut ini bahwa setiap kegiatan kepemimpinan dan kegiatan lain yang ada di sekolah selalu diawasi oleh pihak dinas pendidikan pada saat selalu mengontrol pelaksanaan kepemimpinan di SD/SMP di wilayah Muaro Jambi. Jika terjadi kerusakan maka pihak dinas pendidikan memerintah bawahan untuk memperbaiki. Kegiatan pengontrol yang dilakukan oleh kepala dinas pendidikan memotivasi bawahan untuk lebih baik dalam mengawasi pelaksanaan kepemimpinan sekolah.

Berdasarkan hasil temuan di atas terlihat dan dapat ditarik suatu asumsi bahwa pengawasan yang dilakukan oleh pimpinan memberikan dampak yang positif terhadap kinerja yang dilakukan oleh para bawahannya dan para karyawan. Namun masih ada kekurangan dalam pengawasan yang dilakukan sesuai teori-teori pendidikan yang ada yakni bentuk penilaian, siapa yang menilai dan standar penilaian. Pihak dinas pendidikan diharapkan mempunyai pengaruh yang signifikan pada pembentukan sumber daya manusia (buman capital) kepala dinas pendidikan dalam aspek kognitif, afektif maupun keterampilan, baik dalam aspek fisik, mental maupun spiritual. Hal ini jelas menuntut kualitas penyelenggaraan pendidikan yang baik serta pendidik yang profesional, agar kualitas hasil pendidikan dapat benarbenar berperan optimal dalam kehidupan masyarakat. Untuk itu pendidik dituntut untuk selalu memperbaiki, mengembangkan diri dalam membangun dunia pendidikan. Observasi berikut ini bahwa setiap kegiatan yang ada di sekolah guru selalu diawasi oleh pimpinan dan pengurus. Dengan adanyapengawasan dari atasan guru membuat guru termotivasi dalam bekerja dan berusaha memberikan hasil yang baik ditinjau dari kualitas maupun kuantitas setiap pekerjaan.

Pengawasan merupakan tindak lanjut dari kegiatan penggerakan. Pengawasan dilakukan agar perencanaan yang telah disusun bisa dilaksanakan guru dengan baik. Pengawasan ini dilakukan sejak perencanaan direalisasikan hingga selesai dilaksanakan. Kepala dinas pendidikan dan tahap pengawasan untuk profesionalitas guru bertitik tolak pada tidak kewajiban guru itu sendiri. Diawali dengan guru melaksanakan tugas dengan baik, guru mempersiapkan program pembelajaran, dalam arti guru banyak membaca dan mengembangkan 
kompetensinya. Observasi penulis menemukan bahwa kepala dinas pendidikan melakuka pengawasan terhadap guru terkait pangkat pembelajaran, apakah sudah sesuai dengan apa yang sudah diinformasi sebelumnya.

Keterangan di atas menjelaskan bahwa pengawasan telah dilakukan kepala dinas pendidikan bersama-sama dengan pihak terkait sebagai bentuk tanggung jawab dan menjalankan fungsi atasan dalam rangka pencapaian tujuan pendidikan dalam rangka pengelolaan SDM pendidikan di Kabupaten Muaro Jambi.

Kelima, Peningkatan Prestasi Belajar Peserta didik. Peningkatan prestasi belajar peserta didik di sekolah sangat memerlukan kepala dinas pendidikan yang mandiri dan profesional dengan kemampuan manajemen serta kepemimpinan yang tangguh, agar mampu mengambil keputusan dan prakarsa untuk meningkatkan mutu sekolah. Kemandirian kepala dinas pendidikan diperlukan, terutama untuk memobilisasi sumber daya sekolah dalam kaitannya dengan perencanaan dan evaluasi program sekolah, pengembangan silabus, pembelajaran dan pengelolaan ketenagaan, sarana dan sumber belajar, keuangan, pelayanan peserta didik, hubungan sekolah dengan masyarakat, dan penciptaaniklim pendidikan. Mengenai pelaksanaan tugas kepala dinas pendidikan, berikut wawancara dengan Dinas Pendidikan Kabupaten Muaro Jambi yang mengatakan dinas pendidikan meskipun tidak langsung berinteraksi dengan sekolah dalam pembelajaran sehari-harinya, namun sangat terlihat dalam memajukan sekolah. Bukti nyata dalam hal ini adalah banyaknya peserta didik di Dinas Pendidikan Kabupaten Muaro Jambi yang lulus setiap tahunnya dalam mengikuti Ujian Nasional(UN).

Kepala dinas pendidikan yang demokratis profesional melalui pengangkatan yang profesional juga membantu proses ini. Hal ini akan menumbuhkan iklim demokratis di sekolah, yang akan mendorong terciptanya iklim yang kondusif bagi terciptanya kualitas pembelajaran yang optimal untuk mengembangkan seluruh potensi peserta didik. Kepala dinas pendidikan adalah orang yang benar-benar diharapkan menjadi pemimpin. Oleh sebab itu, kualitas kepemimpinan kepala dinas pendidikan berdampak baik atau buruk bagi keberhasilan prestasi belajar peserta didik di sekolah. Wawancara dengan staf di Dinas Pendidikan Kabupaten Muaro Jambi yang mengatakan peningkatan prestasi peserta didik yang dilakukan dinas pendidikan terlihat dengan persiapan Ujian Nasional (UN) dengan menambah jam pelajaran yang dilakukan pihak dinas pendidikan beberapa bulan sebelum ujian dilakukan. Ini dimaksudkan untuk memberikan banyak kesempatan kepada pesertadidik untuk mendalami materiujian.

Pengamatan penulis di lapangan dimana peningkatan prestasi peserta didik yang dilakukan dinas pendidikan memang terlihat adanya persiapan Ujian Nasional (UN) dengan menambah jam pelajaran yang diadakan beberapa bulan sebelum ujian tersebut.

Wawancara dengan kepala dinas pendidikan yang mengatakan bahwa salah satu tanggung jawab dinas pendidikan dalam peningkatan mutu pendidikan adalah peningkatan pestasi belajar peserta didik. Wujud nyatanya dengan meningkatkan profesionalisme guru, menyediakan sarana belajar yang memadai dan meningkatkan 
waktu belajar peserta didik untuk mendalami materi pelajaran.

Penelitian yang dilakukan di Dinas Pendidikan Kabupaten Muaro Jambi ini mencoba untuk menelusuri langkah-langkah yang ditempuh oleh kepala dinas pendidikan terhadap percepatan pembangunan pendidikan di Dinas Pendidikan Kabupaten Muaro Jambi tersebut. Bimbingan yang dilakukan kepala dinas pendidikan dan guru untuk percepatan pembangunan pendidikan dengan menambah fasilitas pendidikan. Wawancara dengan Kabid SD di dinas pendidikan yang mengatakan untuk percepatan pembangunan pendidikan di Dinas Pendidikan Kabupaten Muaro Jambi, maka saya menambah jam pelajaran di luar jam pelajaran yang ada. Biasanyanya untuk 5 bulan sebelum Ujian Akhir Nasional (UN) dilakukan penmbahan mata pelajaran yang diujikan mulai Nopember sampai april.

Semua mata pelajaran yang diikutsertakan pada Ujian Akhir Nasional (UN) sudah maksimal persiapan ujian peserta didik, maka saya mengajar dengan tambahan jam pelajaran di luar jam pelajaran yang ada. Penambahan jam pelajaran ini memang dikhususnya untuk peserta didik. Untuk percepatan pembangunan pendidikan di Dinas Pendidikan Kabupaten Muaro Jambi secara umum, maka langkah yang dilakukan kepala dinas pendidikan dengan menambah jam pelajaran di luar jam pelajaran yang ada.

\section{Penutup}

Percepatan pembangunan pendidikan di Provinsi Jambi yang dilakukan dengan terbuka menerima saran, pendapat dan kritik terkait pendidikan; memperbaiki sistem informasi kerja dinas pendidikan; peningkatan kinerja pendidik dan tenaga kependidikan di daerah; meningkatkan motivasi dan pengawasan kerja bawahan; dan peningkatan prestasi belajar pesertadidik. Pihak manajemen Dinas Pendidikan Provinsi Jambi harus memberdayakan SDM pendidikan. Dalam perannya sebagai manager, pihak manajemen Dinas Pendidikan Provinsi Jambi dituntut memiliki kemampuan kinerja yang bagus untuk melaksanakan tugas pokoknya dalam rangka mencapai program pemerintah daerah secara maksimal. Kepala Dinas sebagai pengelola yang memimpin kemajuan pendidikan di satu daerah diharuskan membuat perencanaan program tahunan.

\section{Daftar Pustaka}

Sudarwan Danim, Otonomi Manajemen Pendidikan, Bandung: Alfabeta, 2010

Engkoswara dan Aan Komariah, Administrasi Pendidikan, Bandung: Alfabeta, 2010

Dedi Mulyasana, Pendidikan Bermutu dan Berdaya Saing, Bandung: Remaja Rosdakarya, 2012

Edward Sallis, Total Qualiti Management in Education, Terj. Ahmad Ali Riyadi, Yokyakarta: Ircisod, 2006

Abuddin Nata, Kapita Selekta Pendidikan Islam, Jakarta: RajaGrafindo Persada, 2012 
Laporan Keterangan Pertanggungjawaban Gubernur Jambi Tahun Anggaran 2012 MetroJambi, Pembangunan Infastruktur, Dorong Percepatan Pertumbuhan Ekonomi Daerah dan Sektor Rill, Metrojambi.Com Edisi, Senin, 06 Januari 2014 01:07

Sugiyono, Metode Penelitian Pendidikan: Pendekatan Kuantitatif, Kualitatif dan R \&D, Bandung: Alfabeta, 2013

Suharsimi Arikunto, Prosedur Penelitian Suatu Pendekatan Praktik, Jakarta: Bumi Aksara, 2013

Susan M. Drake, Creating Standards-Based Integrated Curriculum: The Common Core State Standards Edition, Terj. Benyamin Molan, California: Teller Road Thousand Oaks, 2012

Wendi Adha, dkk, Pengaruh Akuntabilitas, Ketidakpastian Lingkungan, dan Komitmen Pimpinan Terhadap Penerapan Transparansi Pelaporan Keuangan (Studi Empiris pada SKPD Kota Dumai), Jurnal JOM FEKON Vol. 1 No. 2 Oktober 2014

Syafaruddin, Manajemen Lembaga Pendidikan Islam, (Ciputat: Ciputat Press, 2005 Syaiful Sagala, Kemampuan Profesional Guru dan Tenaga Kependidikan, Bandung: Alfabeta, 2009

Oktavia Pramono, Leadership Setengah Malaikat, Yogyakarta: Syura Media Utama, 2013), hal. 17.

Muhammad Munadi dan Barnawi, Kebijakan Publik di Bidang Pendidikan, Yogyakarta: Ar-Ruzz Media, 2011

Anonim, Optimalisasi Percepatan Pembangunan Daerah Tertinggal di Papua guna Mendorong Peningkatan Kesejahteraan Sosial dalam rangka Memperkokoh Negara Kesatuan Republik Indonesia, Jurnal Kajian Lemhannas RI, Edisi 16, November 2013

Anonim, Profil Kependudukan dan Pembangunan di Indonesia Tahun 2013, Jakarta: BKKBN, 2013

Anonim, Peraturan Presiden Republik Indonesia Nomor 5 Tahun 2010 Tentang Rencana Pembangunan Jangka Menengah Nasional Tahun 2010 - 2014: Buku I PrioritasNasional, Jakarta: Kementerian Perencanaan

Pembangunan Nasional/Badan Perencanaan Pembangunan Nasional (BAPPENAS), 2010

Ernawati, Inovasi Untuk Orientasi Baru Otonomi Daerah, Jurnal Kebijakan Publik, Volume 3, Nomor 2, Oktober 2012 